Article

\title{
Business Education: Filling the Gaps in the Leader's Awareness Concerning Organizational Phronesis
}

\author{
Raysa Rocha * (D) and Paulo Pinheiro \\ Research Center in Business Sciences (NECE), University of Beira Interior (UBI), \\ 6201-001 Covilhã, Portugal; pgp@ubi.pt \\ * Correspondence: geaquinto.rocha@ubi.pt
}

Citation: Rocha, R.; Pinheiro, P.

Business Education: Filling the Gaps in the Leader's Awareness

Concerning Organizational Phronesis. Sustainability 2021, 13, 2274.

https://doi.org/10.3390/su13042274

Academic Editor:

Constantin Bratianu

Received: 19 January 2021

Accepted: 14 February 2021

Published: 19 February 2021

Publisher's Note: MDPI stays neutral with regard to jurisdictional claims in published maps and institutional affiliations.

Copyright: (c) 2021 by the authors. Licensee MDPI, Basel, Switzerland. This article is an open access article distributed under the terms and conditions of the Creative Commons Attribution (CC BY) license (https:// creativecommons.org/licenses/by/ $4.0 /)$.

\begin{abstract}
Education is a method of sharing social consciousness and social reconstruction. There is an existential crisis in business education driven by the conflict between social and financial objectives. A paradigm shift in business education requires that leaders be taught how to incorporate new competencies. Phronesis (practical wisdom), individual and collective, is an essential competence to be addressed in business education. It leads companies to continuous innovation and highly sustainable performance. We conducted 23 interviews with leaders from organizations in 14 countries to discuss some transformations that business education needs through leaders' awareness concerning organizational phronesis. We conducted a thematic analysis of the interviews with support from NVivo software. The results demonstrate gaps in leaders' awareness concerning phronesis and its relationships with knowledge management and organizational spirituality. Business education still needs to be reviewed to enable leaders to learn and incorporate phronesis theory and practice. Building on the gaps found in the leaders' awareness of phronesis, we propose interdisciplinary pedagogical methods to teach business students competencies that enable the embodiment of phronesis. These changes in business education are indispensable to reach sustainability.
\end{abstract}

Keywords: business education; leadership; organizational phronesis; organizational practical wisdom; knowledge management; organizational spirituality; learning organization; sustainability; humanized strategy; NVivo

"I believe, finally, that education must be conceived as a continuing reconstruction of experience, that the process and the goal of education are one and the same thing." John Dewey

\section{Introduction}

We ought to renovate business education to meet society and organizations' necessities [1-4]. Education institutions are social agents influencing progress [5] and sustainability [6]. The dysfunctionality in education hinders social and economic development [7]. The misalignment between the education system and companies hinders the job market [7]. Business schools should be producing employable individuals [4] and practically wise leaders [8]. In a volatile, uncertain, complex, and ambiguous (VUCA) society [9], wise organizations survive by having high sustainable performance, meeting society's and multiple stakeholders' interests [10,11].

As an open system, by the principle of equifinality, organizational phronesis can be achieved by many possible means. There are many approaches concerning organizational practical wisdom [12-14]. We use Rocha and Pinheiro's [15] theoretical framework of organizational practical wisdom. The authors defend that organizational practical wisdom has three levels (individual-leadership and members, workplace, and organization) and results from a successful relationship between knowledge management and organizational spirituality. As well as that, organizational spirituality moderates the relationship between organizational practical wisdom and knowledge management. This research aims to dis- 
cuss some of the transformations that business education needs through leaders' awareness concerning organizational practical wisdom. The research question (RQ) we address is:

RQ: How business education can fill the gaps in the leader's awareness of organizational phronesis (practical wisdom)?

We address this question by conducting qualitative research through thematic analysis, with NVivo 12 assistance, of 23 interviews with leaders from organizations in 14 countries. After identifying the gaps in leaders' awareness of organizational practical wisdom, we propose means to deal with the gaps.

\section{Theoretical Background}

\subsection{Business Education}

Education is a method of sharing social consciousness and social reconstruction [5]. Business education needs transformational reexamination $[1,2,16]$. There is an existential crisis in business education driven by the conflict between social and financial aims [17]. The context of organizational scandals, inequality in society, and climate change requires dedication to social causes [2,17]. The financial burden of education and high competition in education leads to the search for financial success [17]. Business education is part of the system and should contribute to companies with conscious and active members generating social value and sustainable performance [2,18]. Business schools should have social good at the core of their mission [17]. The business curriculum shift should be extensive, as the current curriculum does not meet organizations' and society's needs [1-4].

Design thinking [19] is one of the capabilities required by corporations in a society with high volatility, uncertainty, complexity, and ambiguity [9]. However, it has significance to organizations; soft skills [4], spirituality [20], and phronesis [21] are not part of the business curriculum. Business education needs to be grounded in philosophy to be complete [22]. The integrative use of rationality, emotions, and spirituality would rightly support business persons in complex decision-making [20]. Sustainability leadership implies developing value-driven competencies [23]. The soft part of sustainability has more outputs in empowerment and sustainable behavior than the rational knowledge taught in business education [23].

Teaching is a multifaceted process that involves ongoing learning and review [3]. Students should be active in learning; they should be co-creators of knowledge [24,25]. Business education should focus on education and learning, not on students' satisfaction as customers [24]. Business schools should provide a holistic approach of management to support the development of practical wisdom in the society of a sustainability imperative. Teaching ethics, responsibility, and sustainability is not enough [16]. Business schools should "focus on developing curricula and teaching methods that facilitate thinking conceptually and developing principles" [26] (p. 88). Practical wisdom principles should guide a sustainability curriculum $[16,21]$. Business schools should "teach strategy with the future-we-want-to-make in mind" [27] (p. 8).

\subsection{Organizational Phronesis}

Philosophical practices in companies are essential once they provide insights and means to develop new means of thinking and learning, developing human capital. Marinoff [28] provides some ways to include philosophical interventions in the workplace, "motivational speaking, ethics code-building, ethics compliance, moral self-defense, short Socratic dialogue, dilemma training, leadership and governance tools, and the PEACE process for groups" [28] (p. 160). The ethics code-building is its effective implementation in the workplace, not only the formulation of a code of ethics [28]. "In this context is a manifestation of phronesis" [28] (p. 162).

At the individual level, phronesis is a construct brought about by Aristotle [29] that concerns the correct application of the right means to achieve a good outcome. It is related to living, not to the mysteries of the universe. It is translated as practical wisdom or prudence. 
It is "the right reason applied to action" [30] also as the "right reason applied to the art of living" [31] (p. 89). Phronesis is based on knowledge, reasoning, and action [29,30]. Rational knowledge used to be super valorized [32,33]. Emotional and spiritual knowledge are receiving more attention now [33,34]. Spiritual knowledge is an outcome of the relationship between culture and spirituality. Then, it is our values and beliefs. Spiritual knowledge guides the use of emotional and rational knowledge [33,34].

At the organizational level, "A practically wise organization is both a virtuous and a learning organization" [10] (p. 367). The growth of practical wisdom has an emphasis on experiential development deeply. Beyond Senge's [35] organizational learning five disciplines adaptation (understanding dynamic complexity; developing personal wisdom competency; deliberating towards ethical models; refreshing shared sustainable vision; and group wisdom dynamics) to a stronger ethical orientation, there is the deliberated praxis and the embodiment of learning [10]. Conative and affective features of an organization's experience should be considered the embodiment of practical wisdom [10].

Practically wise organizations have a high level of innovativeness and sustainable performance [11]. Sustainability is a critical strategic matter and has deep spiritual roots [36, 37]. Spirituality influences the intangible parts of sustainability. Therefore, the shift to sustainability is also a shift toward a high spiritual consciousness [36,38]. Zawawi and Wahabi propose that organizational spirituality is the fourth foundation of organizational sustainability. It is the glue bonding environment, social, and economic performance [39]. Spirituality influences sustainable behavior in consumers [40,41]. Hence, to achieve longterm successful sustainable performance, companies should embrace spirituality [42].

\section{Methodology}

The method is a crucial element in investigating intangibles, such as phronesis and leadership. Qualitative methods are still rare regarding leadership [43]. In this section, we explain the qualitative analysis protocol [44]. This article aims to understand leaders awareness regarding the path to incorporating phronesis through exploratory empirical investigation obtained by semi-structured interviews [45-47]. We chose the qualitative method because they are highly subjective phenomena that cannot be entirely quantified [48-51]. Organizational phronesis is a construct recent in the management literature. It is a theory at the beginning of maturation $[10,11]$.

This article pursues discovering new knowledge, understanding the interviewees' awareness, behavior, and habits through primary data [45,46,52]. We developed the semi-structured script based on the literature and did two pre-tests before data collection $[46,53]$. The script is the means appropriate because it grants interviewees' autonomy in their expression and the option of obtaining more in-depth and complex answers to the phenomenon studied [46]. The interviewer explained the concepts of the constructs during the interviews.

We chose the sampling by gradual selection with maximum variation and convenience [46]. The interviewees belong to organizations from different countries (cultures) and sectors, with different sizes, number of members, and income (Table 1). The sampling saturation occurred when the constructs were sufficiently explicated [53].

The unit of analysis is the interviewees (leaders). Twenty-three managers (top and middle) were interviewed electronically, between 2019 and 2020, with computer-assisted telephone interviewing-CATI [54]. We operated by the WhatsApp application and email [54]. CATI has other advantages, such as bringing better interviewer uniformity in delivery, promoting researcher safety, offering a more standardization of questions, and spurring greater cost-efficiency [55]. Thus, CATI lowers factors that influence respondents, such as the interviewer's characteristics (gender, age, race, nationality, social class, and appearance) $[56,57]$.

Qualitative cross-language research is wide-ranging and provides cultural competence to the study [58]. The interviewer conducted the interviews in English, Portuguese, and Spanish. The interviewer transcribed the interviews, initially coded raw data manually, written memos, and the authors did several team meetings [53,59]. The interviews' reading 
and coding were necessary to evaluate and adjust, if necessary, the script. We transcribed without indicating speech changes of the participants; we indicated uncertain and inaudible passages; we ignored repeated words and sounds (mm, uh-huh); we reported only the conventional score, without intonations, volumes, pauses, or stress [52].

Table 1. Characterization of interviewees.

\begin{tabular}{|c|c|c|c|c|c|c|}
\hline Identification & Age & Gender & $\begin{array}{c}\text { Time in the } \\
\text { Organization }\end{array}$ & Country & $\begin{array}{l}\text { Number of } \\
\text { Employees }\end{array}$ & $\begin{array}{l}\text { Organization } \\
\text { Industry }\end{array}$ \\
\hline Interviewee 1 & 38 years old & Female & 20 years & Brazil & 420 & $\begin{array}{l}\text { Brand representation } \\
\text { with carrier }\end{array}$ \\
\hline Interviewee 2 & 29 years old & Female & 9 years & Serbia & 10 & Tourism Agency \\
\hline Interviewee 3 & 40 years old & Male & 4 years & Bulgaria & 40 & $\begin{array}{l}\text { Business Development } \\
\text { Outsourcing Solutions }\end{array}$ \\
\hline Interviewee 4 & 65 years old & Male & 31 years & Argentina & 360 & $\begin{array}{l}\text { Claims settlement } \\
\text { company }\end{array}$ \\
\hline Interviewee 5 & 40 years old & Female & 19 years & Brazil & 80,000 & State Bank \\
\hline Interviewee 6 & 41 years old & Female & 20 years & Brazil & 150 & $\begin{array}{l}\text { Family group with } \\
\text { radio, soccer team, and } \\
\text { college }\end{array}$ \\
\hline Interviewee 7 & 33 years old & Male & 10 years & Brazil & 1600 & Hospital \\
\hline Interviewee 8 & 41 years old & Male & 9 years & Brazil & 300 & Oil Extraction \\
\hline Interviewee 9 & 23 years old & Female & 1 year & Portugal & 29 & Nursing home \\
\hline Interviewee 10 & 40 years old & Male & 2 years & Angola & 10 & $\begin{array}{l}\text { Commerce, Health } \\
\text { Services, and Services. }\end{array}$ \\
\hline Interviewee 11 & 31 years old & Male & 13 years & Brazil & 65 & $\begin{array}{l}\text { Automation, Energy } \\
\text { Telecommunications, } \\
\text { Information, } \\
\text { and Technology }\end{array}$ \\
\hline Interviewee 12 & 58 years old & Male & 28 years & Portugal & 10 & Public Autarchy \\
\hline Interviewee 13 & 37 years old & Male & 1 year & Australia & 3 & Sports School \\
\hline Interviewee 14 & 54 years old & Male & 20 years & China & 10 & Pharmacy \\
\hline Interviewee 15 & 44 years old & Male & 9 years & Indonesia & 46 & Fishing Industry \\
\hline Interviewee 16 & 36 years old & Male & 5 years & USA & 8 & Civil Construction \\
\hline Interviewee 17 & 29 years old & Male & 9 years & Pakistan & 450 & Public Autarchy \\
\hline Interviewee 18 & 52 years old & Male & 4 years & Spain & 8 & Food imports \\
\hline Interviewee 19 & 46 years old & Female & 1 year & France & 150 & Textile sector \\
\hline Interviewee 20 & 51 years old & Female & 24 years & South Africa & 3000 & Academic Institution \\
\hline Interviewee 21 & 55 years old & Female & 20 years & Brazil & 8 & Physical therapy clinic \\
\hline Interviewee 22 & 31 years old & Female & 6 years & Brazil & 8 & Food retail \\
\hline Interviewee 23 & 49 years old & Female & 27 years & USA & 10 & Insurance Broker \\
\hline
\end{tabular}

\section{Results Analysis}

We choose to analyze the results through thematic analysis [44,53]. We used analytics tools to explore the interviews, such as thinking about a word with several meanings, making comparisons, and questioning [44]. We did the interviews' mimetic analysis through the symbolic interactionism theory and interpreted it by thematic analysis [53]. We did an early reflection on the collected data in the thematic analysis, we reviewed the literature during transcription and interview analysis and took notes [52,53].

We analyzed it with computer-aided qualitative data analysis software-CAQDAS to increase efficiency and effectiveness. We used the software NVivo [60,61]. We categorized and coded the excerptions $[52,53,60,61]$. We classified relevant interventions for the discussion according to the literature. We used both deduction and induction in coding. Other codes have emerged from the responses alongside the codes originating from the 
concept analyzed [52]. We did a micro-analysis only in the first interview because there were no contradictions to solve in the following [60]. We "sliced" some passages of the interviews since they shared more than one code. It provides a stratified assessment of the selection and its meaning. This simultaneous multiple-coding captures what is happening in a quote [60].

After coding, we conducted a careful checking of coding with a "Compound Query" [60]. We ran a code retrieval (coding stripes) to support and clarify the codebook [61]. Nevertheless, there are synonymous words and expressions that NVivo cannot discover. Consequently, before and after the coding process, we did a line-by-line reading to ensure the analysis's depth and robustness [61].

The first analysis we did with NVivo was "Word Frequency Query" [60,61]. It used the succeeding selection criteria (a) with stemmed words, (b) 100 most frequent words, and (c) with "three" minimum length by default. We withdrew words like "company" and "organization" because there were a large presence and an absence of its utility in the analysis. Figure 1 below illustrates the result.

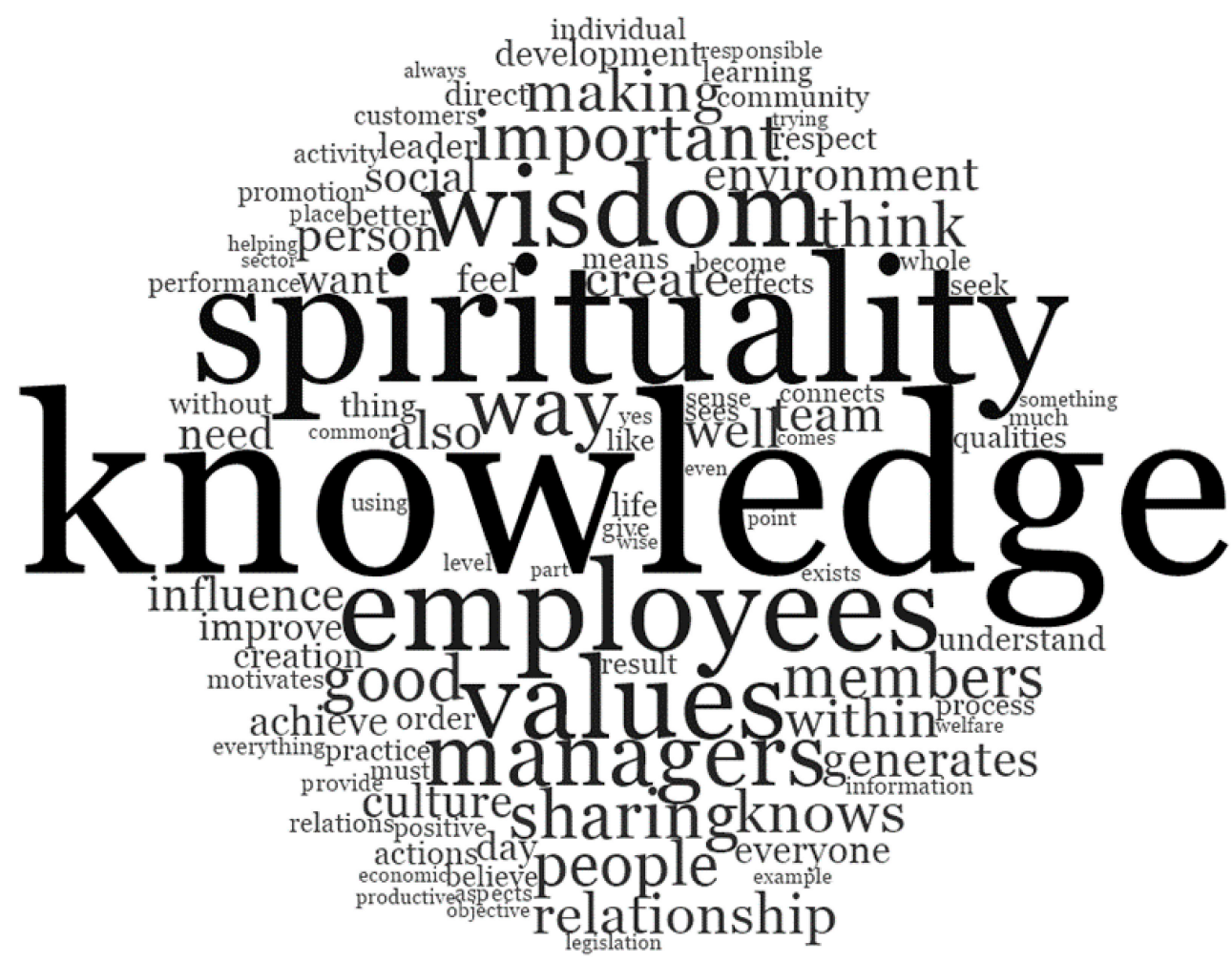

Figure 1. A word cloud of the most frequent words (NVivo 12).

The word cloud displays the 100 words most repeated by interviewees. Words like knowledge, spirituality, wisdom, employees, values, way, and managers are in the center of the cloud in a larger size because they were the most repeated words. Moving from the center towards the edge of the cloud, we infer smaller sizes letters because they were the lesser repeated words in the list. Dividing the 100 most repeated words into four levels, we observe that verbs are mainly in the third and fourth levels, while subjects and substantives are in the first two.

The position and size of the word are related to its repetition and closeness in the answers. Knowledge is in the center of the figure, and the words near are the actor in the company (employees, members, team, managers, and people) and action words (give, influence, improve, creation, achieve, provide, generates, and understand). Spirituality is above with more philosophical words around (feel, want, means, sense, seek, connects, 
and way). Wisdom is the most significant word displayed above spirituality and has words concerning the company's exterior (environment, social, community, and customers).

As a result of the "Word Frequency Query", NVivo, by default, categorized the most frequent words into ten clusters $[60,61]$. This separation by clusters (Figure 2) signifies their proximity in the interviewees' answers. NVivo does not explore interviewees' positive or negative feelings towards the words in this resource.

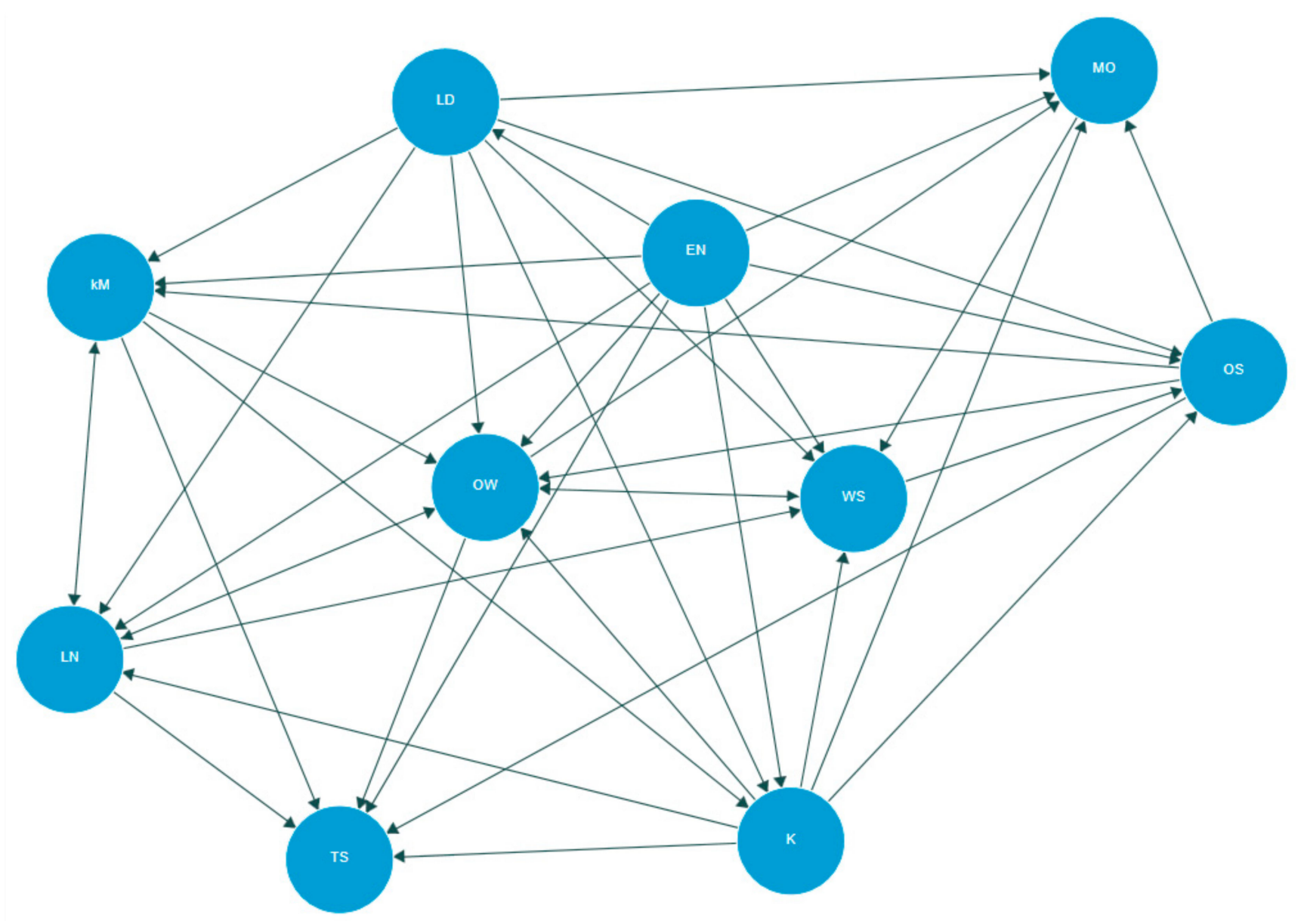

Figure 2. Most frequent words by clusters (NVivo 12).

To categorize clusters, we identify them based on the constructs that are part of the codification: 1. Leadership (LD); 2. Transformation (TS); 3. Environment (EN); 4. Learning (LN); 5. Workplace spirituality (WS); 6. Organizational spirituality (OS); 7. Knowledge (K); 8. Practical wisdom (PW); 9. Marketing-orientation (MO); and 10. Knowledge Management (KM). Figure 2 displays the connection between the clusters.

After that analysis, we explored the existence or absence of correlation between organizational practical wisdom, knowledge management, and organizational spirituality constructs through the word similarity. It is the coding clustered by word similarity using the Pearson correlation coefficient (NVivo 12).

Organizational practical wisdom presents a strong positive correlation with organizational spirituality and a moderate correlation with knowledge management. This positive correlation signifies that the variables move in the same direction. In contrast, there is no significant correlation between knowledge management and organizational spirituality (Table 2). The moderate correlation between organizational practical wisdom and knowledge management results from the interviewee's shortage of theoretical expertise concerning the constructs. Rocha and Pinheiro's [15] theoretical framework of organizational practical wisdom defends a moderator effect of organizational spirituality in the relationship between knowledge management and organizational practical wisdom. Nevertheless, 
NVivo does not analyze that kind of effect. Figure 3 is the result of a correlation between $\leq 1$ and $\geq 0.5$ (Table 2 ).

Table 2. Codes clusters by word similarity using the Pearson correlation coefficient (NVivo 12).

\begin{tabular}{ccc}
\hline Code A & Code B & $\begin{array}{c}\text { Pearson } \\
\text { CorrelationCoefficient }\end{array}$ \\
\hline $\begin{array}{c}\text { Codes } \backslash \backslash \text { Organizational } \\
\text { Spirituality }\end{array}$ & $\begin{array}{c}\text { Codes } \backslash \backslash \text { Organizational } \\
\text { Practical Wisdom }\end{array}$ & $0.844^{* * *}$ \\
\hline $\begin{array}{c}\text { Codes } \backslash \backslash \text { Organizational } \\
\text { PracticalWisdom }\end{array}$ & Codes $\backslash \backslash$ KnowledgeManagement & $0.666^{* *}$ \\
\hline $\begin{array}{c}\text { Codes } \backslash \backslash \text { Organizational } \\
\text { Spirituality }\end{array}$ & Codes $\backslash \backslash$ KnowledgeManagement & $0.496^{*}$ \\
\hline
\end{tabular}

Note: $\left(^{* * *}\right)$ strong correlation; $\left(^{* *}\right)$ moderate correlation; $\left(^{*}\right)$ no correlation.

\section{Items clustered by word similarity}

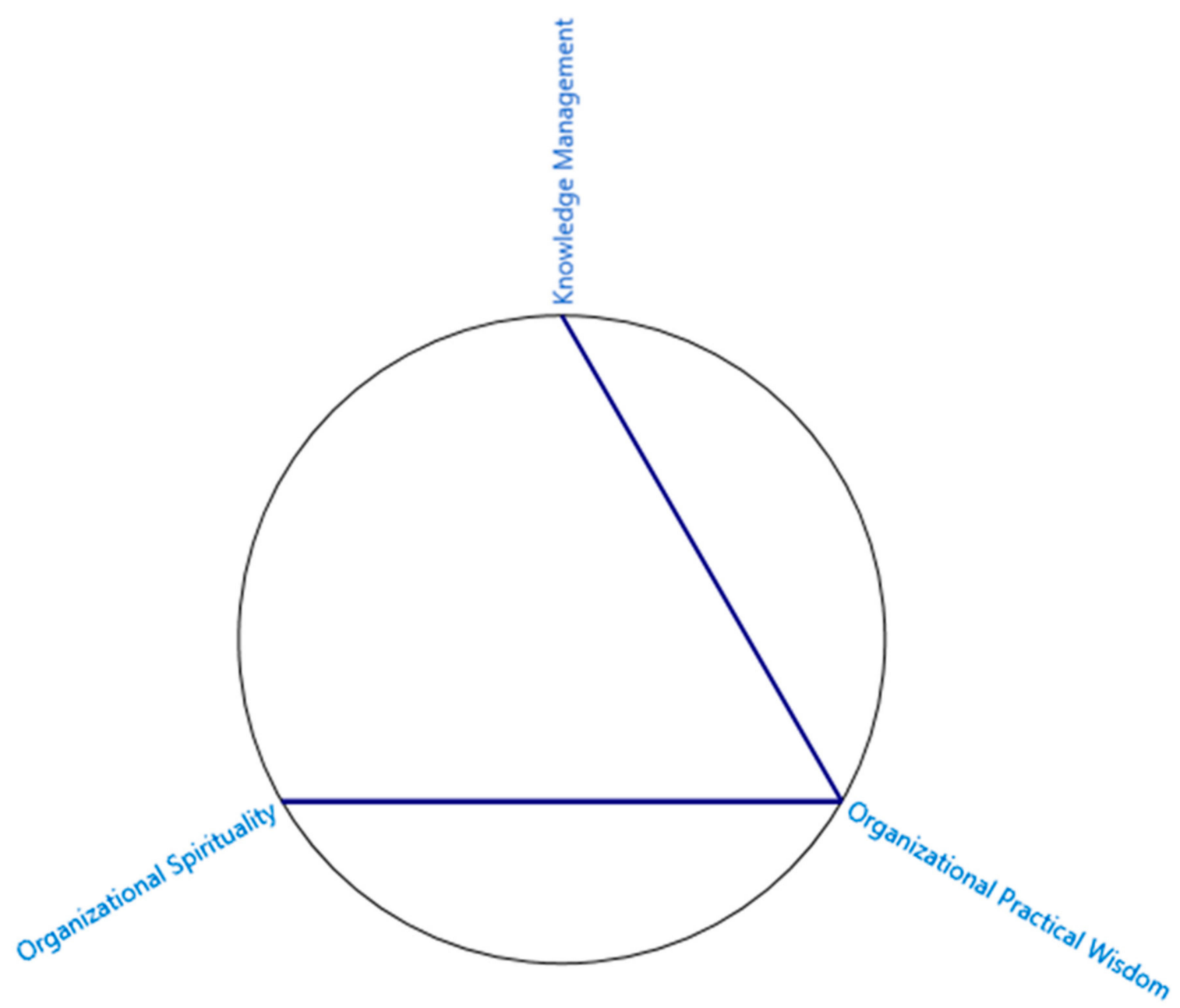

Figure 3. Diagram of codes cluster analysis by word similarity using the Pearson correlation coefficient (NVivo 12).

We also analyzed the linking between the answers and the codes. NVivo provided a matrix displaying how much each code is present in each interview (Figure 3), the "Matrix Coding Query" (Figure 4 and Table 3). It supports exploring patterns across the unity of 
analysis [61]. The disparity in the number of codes among the first interview and the others refers to the micro-analysis [60] and the fact that it is the most extended interview.

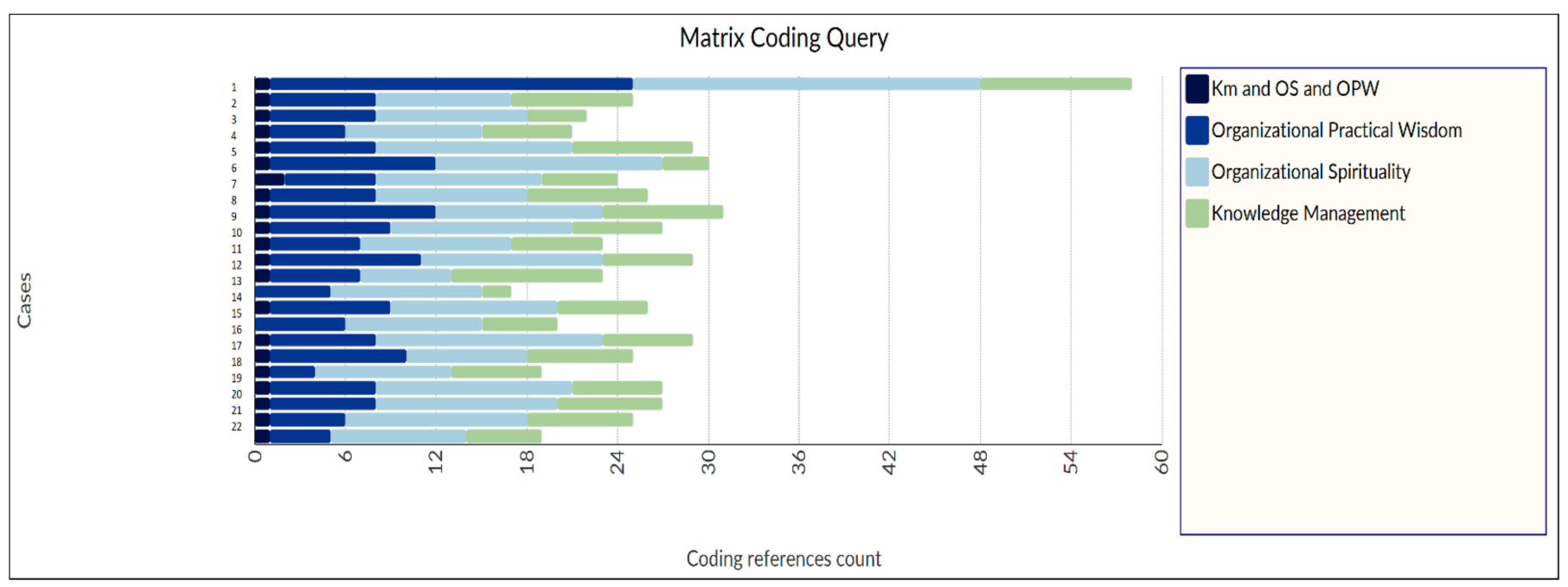

Figure 4. Matrix Coding Query Chart (NVivo 12).

Table 3. Matrix Coding Query (NVivo 12).

\begin{tabular}{|c|c|c|c|c|}
\hline & $\begin{array}{c}\text { KM and OS and } \\
\text { OPW }\end{array}$ & $\begin{array}{l}\text { Knowledge } \\
\text { Management }\end{array}$ & $\begin{array}{l}\text { Organizational } \\
\text { PracticalWisdom }\end{array}$ & $\begin{array}{c}\text { Organizational } \\
\text { Spirituality }\end{array}$ \\
\hline 1 & $14.43 \%$ & $8.44 \%$ & $14.08 \%$ & $7.43 \%$ \\
\hline 2 & $9.55 \%$ & $5.93 \%$ & $6.45 \%$ & $10.59 \%$ \\
\hline 3 & $2.1 \%$ & $2.33 \%$ & $1.63 \%$ & $1.99 \%$ \\
\hline 4 & $8.2 \%$ & $6.36 \%$ & $6.1 \%$ & $5.37 \%$ \\
\hline 5 & $7.45 \%$ & $14.3 \%$ & $6.9 \%$ & $7.22 \%$ \\
\hline 6 & $0 \%$ & $0.24 \%$ & $0.73 \%$ & $1.09 \%$ \\
\hline 7 & $5.49 \%$ & $5.23 \%$ & $7.81 \%$ & $9.06 \%$ \\
\hline 8 & $0 \%$ & $2.1 \%$ & $3.33 \%$ & $2.94 \%$ \\
\hline 9 & $2.78 \%$ & $4.84 \%$ & $4.71 \%$ & $7.32 \%$ \\
\hline 10 & $0.75 \%$ & $2.05 \%$ & $1.55 \%$ & $1.2 \%$ \\
\hline 11 & $0.07 \%$ & $1.66 \%$ & $0.8 \%$ & $1.05 \%$ \\
\hline 12 & $1.49 \%$ & $5.06 \%$ & $3.84 \%$ & $2.3 \%$ \\
\hline 13 & $2.44 \%$ & $3.26 \%$ & $4.08 \%$ & $4.06 \%$ \\
\hline 14 & $0.27 \%$ & $1.43 \%$ & $0.93 \%$ & $2.74 \%$ \\
\hline 15 & $1.15 \%$ & $2.14 \%$ & $4.69 \%$ & $4.96 \%$ \\
\hline 16 & $2.57 \%$ & $1.59 \%$ & $1.28 \%$ & $1.85 \%$ \\
\hline 17 & $2.37 \%$ & $1.84 \%$ & $2.7 \%$ & $2.46 \%$ \\
\hline 18 & $1.69 \%$ & $3.19 \%$ & $2.03 \%$ & $2.07 \%$ \\
\hline 19 & $4.67 \%$ & $4.32 \%$ & $4.1 \%$ & $4.39 \%$ \\
\hline 20 & $0.68 \%$ & $0.55 \%$ & $3.52 \%$ & $2.97 \%$ \\
\hline 21 & $1.83 \%$ & $1.17 \%$ & $1.32 \%$ & $1.75 \%$ \\
\hline 22 & $2.64 \%$ & $6.67 \%$ & $4.52 \%$ & $4.67 \%$ \\
\hline 23 & $27.37 \%$ & $15.32 \%$ & $12.9 \%$ & $10.53 \%$ \\
\hline
\end{tabular}

NVivo displays the same Matrix Coding Query in a table with the code percentage (Table 3). Its cells show the code percentage that each interview contributed. That is, each cell expresses the percentage that the interview contributed to the codification in the 
column. Some interviewees had more contributions on specific codes than others. This expression is merely quantitative without qualitative examination.

The analysis of how much each interviewee contributed with a code displays that, despite not being a content analysis, their answers include more organizational spirituality while organizational practical wisdom and knowledge management had fewer contributions (Table 3 and Figure 4). The code concerning the relationship between these constructs had even less content. In Table 4, we display excerpts with gaps. Emphasizing that the lack of an answer is also a gap in leaders' awareness regarding the constructs. Thus, the disparity in each construct answer's length reflects the gaps' identification (Table 3 and Figure 4). For instance, in Table 4, the answer "Vital!" (i19) demonstrates that the interviewee has some knowledge about it, but it is not deep, while the answer "Unfortunately, not" (i7) demonstrates that there is not any awareness regarding the question and that the interviewee would like to have. Both answers are concise, part of the codification, and identify gaps in leaders' awareness.

Table 4. Interviews' excerpts by code.

\begin{tabular}{|c|c|}
\hline CODES & EXCERPTS \\
\hline $\begin{array}{c}\text { Organizational Practical } \\
\text { Wisdom }\end{array}$ & $\begin{array}{c}\text { "Even though I am new to the market, I consider my organization to be wise from the point of view } \\
\text { of the definition of wisdom" (i10) } \\
\text { "Personal presentation of salesmen, education, kindness, putting into practice the mission, } \\
\text { vision of the company" (i18) }\end{array}$ \\
\hline Knowledge & $\begin{array}{l}\text { "As far as the creation of knowledge sharing by my organization is concerned, we have not gotten there yet, } \\
\text { because we are new; however, we have been in the market for a little less than a year, but it is part of the } \\
\text { organization's strategy to create workshops, so much to create some lectures at least to let people know that we } \\
\text { exist and that society can really count on us" (i10) }\end{array}$ \\
\hline Spirituality & $\begin{array}{l}\text { "We have a chaplaincy sector that periodically promotes spiritual actions with patients and employees" (i7) } \\
\text { "Unfortunately, not" (i7) } \\
\text { "Organizational Spirituality cannot be taught in training. It will exist as a consequence of the good environment } \\
\text { provided by the organization. Knowledge generates safer, more confident employees, aware of their importance } \\
\text { in the organization's environment and the community" (i23) }\end{array}$ \\
\hline Outcomes & $\begin{array}{l}\text { "It generates economic values through much work that we have. Values are created through the work we do" (i16) } \\
\text { "The organization generates value and social good through individual rules that guide internal decisions and } \\
\text { actions. Businesses are managed in accordance with laws, regulations, and guidelines, and processes are } \\
\text { structured in an integrated manner with all interest groups" (i6) } \\
\text { "The generation of values and social good that my organization produces, I believe, is to guarantee employment, } \\
\text { therefore, to young people, on the other hand, that they are heads of families, and I believe, that the amount that } \\
\text { they earn as an income can support their families" (i10) } \\
\text { "Through the pursuit of its mission and its tasks" (i12) } \\
\text { "We usually make donations. (...) We do not consider our organization wise; our only visual aspects are the } \\
\text { medicine donated and free service to the poorest people or those in need" (i14) } \\
\text { "Now I have not done any social good yet, only generating values through work. In the future, I will want to do } \\
\text { some social good yet, to share a little of the profit" (i16) } \\
\text { "We encourage the team to provide personalized customer service, meet deadlines for delivery of goods and } \\
\text { supply of first-class products" (i18) }\end{array}$ \\
\hline KM OS and OPW & $\begin{array}{l}\text { "That two things most go one with each other. They are like siblings, } \\
\text { so you can have one and do not have another" (i2) } \\
\text { "15. \& 16. I felt I answered. To put it frankly, however, this is about making money and monopolizing on } \\
\text { outsourcing work to drop costs. That means someone loses a job, and someone gets one. } \\
\text { The business has a shadow and light side" (i3) } \\
\text { "When the manager knows how to express himself, } \\
\text { without creating a negative environment" (i8) } \\
\text { we knows how to reach the subconscious of the workforce, he achieves the commitment of all in an integrated way, } \\
\text { without needing to be arrogant, } \\
\text { "Profound question, I do not know how to answer that question" (i14) } \\
\text { "I am going to skip that question because I do not know how to answer you" (i16) } \\
\text { "Vital!" (i19) } \\
\text { "Employees must feel valued and motivated and should be given an overview of the systems in the organization } \\
\text { to ensure that it is knowledge-related assets are important and effectively employed in } \\
\text { day-to-day organizational activities" (i20) } \\
\text { "Fostering and consolidating values" (i21) }\end{array}$ \\
\hline
\end{tabular}


In this section, we scrutinized the interviewees collectively, with the analyses provided by NVivo 12. In the following section, we answer the research question by discussing the most representative interviews and excerpts to identify the gaps to proposing means to fill it by transforming business education.

\section{Discussion}

Our focus in the discussion is to answer the research question: How business education can fill the gaps in the leader's awareness of organizational phronesis (practical wisdom)? Consequently, in this research, we do not discuss what leaders are fully aware of. In Table 4, we display some excerpts of interviewees' answers. We chose some excerpts, highlighting the gaps in leaders' awareness concerning phronesis and its relationships with knowledge management and organizational spirituality. After presenting the gaps in leaders' awareness concerning organizational practical wisdom, we propose business education suggestions. Therefore, the discussion regarding the gaps is the core of our suggestions in business education. We divided this section into organizational phronesis, organizational spirituality, knowledge management, and propositions to the paradigm shift in business education. Our driving aim is to include phronesis theory and practice. Hence, we also discuss suitable pedagogical means to teach phronesis in business education.

\subsection{Organizational Phronesis}

A practically wise organization has practically wise leaders at all levels [11]. They are able to apply rational, emotional, and spiritual knowledge to efficiently do good. They are aware of their company characteristics and provide improvement to their weak points. Interviewee 10 affirmed that his company does not share knowledge, yet he believes that his company is wise (Table 4). The lack of awareness about practical wisdom indicates that business schools should teach students about it [21] and spiritual knowledge [62]. In business education, we should go beyond soft skills and emotional intelligence [20,36]. Values and spirituality in organizations are related to increasing performance [63-65] and sustainability [36] because spiritual knowledge built on positive values enables people to find meaning in their work [62].

A practically wise company's outcomes are both economic value and social good, achieving longevity through a highly sustainable performance [11]. In the word cloud (Figure 1), the words that interviewees related to wisdom in their answers are visible. Concerning economic value, it should come from continuous innovation and the best use of means. About social good, it should meet society and customers' desires doing the best for stakeholders and future generations [11,36]. Spiritual knowledge allows students to understand that a business's real mission is to create value for society [62]. Interviewee 16 reveals that his company does not do any good to society, not with its main purpose (interviewee 12), nor with the jobs created (interviewee 10). Interviewee 14 does good through donation and free service to the poor. How to build an organizational mission involving doing good to society should be part of the business curriculum. Such as innovations and entrepreneurship focusing on solving social problems and making better solutions to recurring local issues.

When asked about the relationship between knowledge management, organizational spirituality, and organizational practical wisdom, two interviewees (18 and 23) did not answer. Two others acknowledged that they do not know how to answer it (14 and 16). Among the interviewees, there is the belief that one cannot teach spirituality (23). Nevertheless, culture and religion influence values and spiritual practices. Usually, it is taught through the first socialization [66]. Although spiritual knowledge has a high level of order and a low level of entropy [34], it can be taught in the second socialization [66]. Through an active learning process and student-teacher partnership, business education should re-educate students to embody a new values system [25,67].

Interviewees' answers concerning organizational phronesis and its relationship with knowledge management and organizational spirituality support that leaders should im- 
prove those constructs alongside organizational phronesis given its correlation (Table 2 and Figure 3). In the following Sections 5.2 and 5.3, we discuss the gaps in leaders' awareness concerning knowledge management and organizational spirituality that can influence organizational phronesis.

\subsection{Knowledge Management}

Knowledge management is any deliberate effort to manage companies' labor force knowledge. It can be reached through an extensive range of methods [68]. It supports learning by providing means to achieve it; thus, each company has an approach. Learning is a means to transform society and individual's mindsets and mental models [35,69]. Knowledge management has a role in changing how employees learn and adding value to rational knowledge through spiritual knowledge [33,34,62].

In Western cultures, there is still over valorization of rational knowledge [34]. Interviewees' discourse is in the same direction. In the word cloud (Figure 1), the words that interviewees related to knowledge in their answers are visible. Training and staff meetings were the most mentioned means of sharing knowledge, while bond activities had less participation. Techniques to memorize rational knowledge are outdated strategies, mainly due to the easy access to information. Business schools should accentuate the importance of other types of knowing, sharing, and the means to improve the intention to share and the absorption of shared knowledge. Art and architecture can help business students develop a different kind of knowing, grounded in emotion and context [70]. The integration between emotional and spiritual knowledge drives motivation and changes behavior [62]. This transformation belongs to the path towards phronesis.

Knowledge dynamics need a dynamic existential ambiance, a $B a$ (context, space, time, configuration, and social elements) [71]. In industrial society, a workplace is an exact place, while in the knowledge society, the workplace can be anywhere [71]. Hence, culture, size, and the structure of each company are related to its $B a$ [71]. The interviewees perceive the shared context $(\mathrm{Ba})$ only as physical places (meeting room, auditorium, and classroom) where members share rational knowledge. They had difficulty answering the question concerning it. Most of them did not understand the mental and virtual existence of $B a$. Nonaka and Takeuchi's [11,72] model's cultural embeddedness is a limitation $[33,71,73]$ that should be acknowledged. Still, the importance of a shared context that fosters knowledge sharing and organizational learning should be taught in business schools, alongside how to develop and maintain this free form ambiance.

\subsection{Organizational Spirituality}

Due to spirituality's early development stages in management studies, there is still confusion about its concept [74]. Interviewee 22 acknowledged that they had "never actually heard the term organizational spirituality" and interviewee 8 that they "do not have the necessary knowledge to answer you, so I will not be able to help you". In the word cloud (Figure 1), the words that interviewees related to spirituality in their answers are visible. For example, the word value is far from it in the cloud and consequentially in the answers. The scarcity of awareness of it is also present in the questions not answered. Interviewees (i1, i8, i10, i13, i17, and i18) skipped at least one question (questions 7, 10, 13,14 , or 15) regarding this subject. Even a leader's role in embodying organizational spirituality [62,74-76] is not perceived. Interviewee 7 said, "I do not see the leaders" participation in that". Business schools should include spirituality in leadership education. It is a continuous process based on social interactions that produce meanings [77], and spirituality adds value to that process [76].

Organizations find profitability enhancing the tangible part of sustainability [36]. However, not so many transformed their profit-oriented value systems to transcendental sacred values of nature and life [36]. Interviewee 23 believes that spirituality cannot be taught. It is a belief that obstructs the evolution of spiritual knowledge into spiritual intelligence. It "implies a capacity for a deep understanding of existential questions and insight 
into multiple levels of consciousness. Spiritual intelligence also implies an awareness of spirit as the ground of being or as the creative life force of evolution" [78] (p. 19). Numerous methods can develop it. "Spiritual maturity implies exercising wisdom" [78] (p. 19). Business schools should teach students the means to exercise attention, convert emotions, and promote virtuous behavior to build spiritual intelligence [78]. It grows capabilities concerning the intangible part of sustainability and achieves higher-level values to guide the business transformation.

After discussing the gaps (Table 4) in the leaders' answers concerning organizational practical wisdom in the previous topics, we offer some suggestions to renovate business education through the teaching of phronesis.

\subsection{Business Education}

After identifying the gaps in this topic, we propose some transformations in business education. There is no formula to the fundamental shift in business education nor to conquer practical wisdom. Each business school will have a transformational path [2]. It is necessary to reframe business education's purpose and values, redefining the meaning of professional success [17]. Our suggestions aim to place philosophy as the basis of business education [22] to improve students learning and embodiment of phronesis [21] by offering them an active role in value-based education [16,25] and addressing job market needs [7].

Business schools ought to recognize that business leaders possess the power to shape and guide their organizations and society $[2,16]$. They need to create character strength and a profound sense of awareness of their moral purpose [2], refining "future global citizens" [16]. To teach that, business schools also must have a sense of purpose and calling [2], reviewing their raison d'être [16]. They should acknowledge the incompleteness of "techne-oriented education" [21] and the value of spiritual and emotional knowledge in decision-making, "why" and "how" apply rational knowledge [2]. Spirituality belongs to a person's singularity; therefore, there is no way to imitate one spiritual capability because it is complex, causally ambiguous, and holistic [36].

Centers for sustainability in universities or business schools are a means of genuine integration of sustainability in business school practices [79]. It requires technical, political, and cultural fits to achieve success. The political fit supports the values and provides resources to technical fit. It enhances the brand and reinforces the alignment of values. The cultural fit supports collaboration and the leader's power [79]. Sustainable development goals [80] can serve as a guide for incorporating phronesis into business education. The 17 United Nations (UN) goals [80], individually and collectively, can be put into design thinking exercises in which a given company wants to make changes to its products and services and/or its manufacturing process to comply with some of these goals, such as gender equality (5th goal), decent work and economic growth (8th goal), and industry, innovation, and infrastructure (9th goal) [80]. In this example, the teacher asks the students to think about how the given company would make these changes in an innovative and forward-looking approach that generates positive results for both the company and society. Phronesis can be applied in all decision-making, and therefore in all dimensions of the UN sustainable development goals.

Mckenna and Biloslavo [21] suggest the use of practical wisdom principles to guide business education. Business school should focus on teaching how to be practically wise, how to embody phronesis. Leaders who apply rational knowledge without moral virtues (spiritual knowledge) cause many of society's problems today [2]. Rational knowledge must be only a part of the knowledge used in decision making. They also ought to use emotional and spiritual knowledge [2,33]. A multidisciplinary approach, including art and architecture, can enhance sensibility to a different kind of knowing, with emotion and context. Personal experience is the key to develop practical wisdom [81] and to learn other learning methods [70]. Brainstorming could be replaced by "bodystorming". "Instead of mere thinking in a brainstorming session, bodystormings are sites that are designed for experiencing with the whole body how the products and materials interact with each 
other and what the possibilities and limits of using them are" [81] (p. 39). Business schools also need to teach language skills with activities involving figures of speech, storytelling, rhetoric, and virtual means of communication that should be included in the curriculum. So, values, humanized strategy, and phronesis are spread both by actions and organizations' discourse and their members [27].

Wisdom is based on reason and knowledge; it incorporates non-rational and subjective elements into decision-making; it is directed to authentic, humane, and virtuous results; it is articulate, aesthetic, and intrinsically fulfilling; and it is practical [21]. Those principles should guide relevant pedagogic skills, such as moral imagination, critical skills, alterity, understanding our humanity and values, global in scope and local in values/knowledge, and the virtuous mean and balance [21]. At the organizational level, these competencies support spirituality engendering a long-term successful sustainable performance [42].

First, high-level spiritual knowledge (values) must be incorporated into the decisionmaking process. Real situations should be used as the base for simulations. It is a chance to incorporate philosophical practices, such as dilemma training [28]. Moreover, an occasion to foster critical thinking in the suitable approach to business education, social normsperspective [82]. This training should also include abductive reasoning [19] in problem resolution. Experiential learning provides a personal bond between the business and focuses solutions [23]. Continuous experimentation supports student-teacher partnership in sustainability education [25]. Students should have to learn how to deal with conflicts of interest (both inter- and extra-firm), to go further at the learner's paradox (acknowledge the ignorance, flexibility to changes, setting aside preconceptions), and that time is a relation between events (it is not static or neutral) [83]. To teach students to be open to learning, the teacher should provide a safe context, which is non-judgmental [25]; the primary teaching is what they believe and how they live [20].

In more advanced stages, students must be integrated into the community. With business projects in the community [23], they should learn how to choose and apply better means to solve community issues through business. Teachers could combine it with research-action investigations, a case in which the possible solutions will be put into practice and analyzed scientifically. Recent examples happened during the COVID-19 pandemic. Many factories shifted their production to aid the fight against coronavirus and survive the pandemic $[84,85]$. They changed to provide what society needed and to maintain jobs. It was not an easy change, and it had to be done quickly [84]. It is a situation that teachers can use in projects with the "studio model" and "design thinking" approaches [70]. These pedagogical models give students the protagonism in learning. They experiment in learning how to understand and decompose "wicked problems" with a new approach [70].

Mentoring programs with a deep immersion in different environments and cultures [23] can provide global thinking [21] with diversification of reality perception, enhancing empathy, creativity, and altruism. It is another chance to use dilemma training incremented with cultural and social distinctions. Students will be able to understand the different challenges and how to address them. They will have the opportunity to build a network and interact with others to inspire them [23].

Business schools are suffering pressure due to globalization and technological development [86]. The COVID-19 pandemic required remote teaching as a solution during lockdowns. Business schools should prepare themselves to use artificial intelligence, big data, machine learning, the internet of things, augmented reality, and others, not only virtual platforms [87]. In closing, there are many changes necessary in business schools to prepare students to deal with companies in a VUCA environment and post-pandemic scenario. 


\section{Conclusions}

To discuss how business education can fill the gaps in leaders' awareness concerning organizational practical wisdom, we conducted 23 interviewees with a thematic analysis using NVivo 12 assistance. This support augments this research's reliability, transparency, and trustfulness [61]. Our study offers guidance on how transforming business education can lead to developing practically wise leaders and employees.

This study's theoretical contributions are the empirical testing of the theoretical framework proposed by Rocha and Pinheiro [15]. Although there is a strong theoretical foundation, leaders still need to be aware and to embody phronesis to begin the path to become a practically wise organization. Undergraduate, master's, and MBA business courses must be reformulated and what should be renovated is a concern. This research's practical contributions diagnose the gaps in leaders' awareness concerning organizational practical wisdom alongside the propositions to solve the issue.

Despite all the contributions, there are limitations. This research is a starting point, and it cannot be generalized. The cultural and gender effects were not considered. The participants were very solicitous and willing to answer, but using lingua franca in some interviews may have caused communication noise. A warning, endogenous issue in the research of spirituality should be considered in the heuristics processes. On the same topic, academics and practitioners should avoid excessive positivity.

The investigation concerning practical wisdom in management is in its early stages. To enlighten future research, we provide suggestions. First, to investigates business students' and organizations members' awareness concerning organizational practical wisdom. Second, to do longitudinal studies in organizations with a high level of organizational practical wisdom. To do empirical testing (experiments, for instance) with the propositions to transform business education. To research how organizational spirituality influences organizational learning and the development of soft skills.

Author Contributions: Conceptualization, R.R. and P.P.; methodology, R.R. and P.P.; software, R.R.; formal analysis, R.R.; investigation, R.R.; resources, R.R.; writing-original draft preparation, R.R.; writing-review and editing, R.R. and P.P.; supervision, P.P. All authors have read and agreed to the published version of the manuscript.

Funding: This work was supported by the NECE-Research Center in Business Sciences funded by the Multiannual Funding Program of R\&D Centers of FCT-Fundação para a Ciência e Tecnologia, Portugal, under Grant UIDB/04630/2020; and Research Grant sponsored by Santander Totta.

Institutional Review Board Statement: Not applicable.

Informed Consent Statement: Not applicable.

Acknowledgments: We greatly thank all who were willing to respond and mediated the contact with leaders.

Conflicts of Interest: Authors declare no conflict of interest.

\section{References}

1. Bratianu, C.; Hadad, S.; Bejinaru, R. Paradigm Shift in Business Education: A Competence-Based Approach. Sustainability 2020, 12, 1348. [CrossRef]

2. Hoffman, A.J. Business education as if people and the planet really matter. Strateg. Organ. 2020. [CrossRef]

3. MacAulay, K.D.; Mellon, M.J.; Nord, W.R. Reorienting business education through the lens of Ernest Boyer. Am. J. Bus. 2020, 35, 45-59. [CrossRef]

4. Nusrat, M.; Sultana, N. Soft skills for sustainable employment of business graduates of Bangladesh. High. Educ. Ski. WorkBased Learn. 2019, 9, 264-278. [CrossRef]

5. Dewey, J. My Pedagogic Creed. Sch. J. 1897, 54, 77-80. [CrossRef]

6. Ibidunni, A.S.; Ibidunni, O.M.; Akinbola, O.A.; Olokundun, M.A.; Ogunnaike, O.O. Conceptualizing a teacher-student knowledge exchange perspective: Exploring the tripartite relationships between SECI theory, LMX theory and HEIs' students' preparedness for the workplace. High. Educ. Ski. Work-Based Learn. 2020. [CrossRef]

7. Alam, G.M.; Roslan, S. Contribution of prejudiced clustering education system in developing horizontal and vertical mismatch in job market: Quality of employees in banking sector. Bus. Process Manag. J. 2020. [CrossRef] 
8. McKenna, B.; Rooney, D. Wise Leadership. In The Cambridge Handbook of Wisdom; Cambridge University Press: Cambridge, UK, 2019; pp. 649-675, ISBN 9781108568272.

9. Schick, A.; Hobson, P.R.; Ibisch, P.L. Conservation and sustainable development in a VUCA world: The need for a systemic and ecosystem-based approach. Ecosyst. Health Sustain. 2017, 3, e01267. [CrossRef]

10. Rowley, J.; Gibbs, P. From learning organization to practically wise organization. Learn. Organ. 2008, 15, 356-372. [CrossRef]

11. Nonaka, I.; Takeuchi, H. The Wise Company: How Companies Create Continuous Innovation; Oxford University Press: New York, NY, USA, 2019.

12. Swartwood, J. Can we measure practical wisdom? J. Moral Educ. 2020, 49, 71-97. [CrossRef]

13. Rowley, J.; Slack, F. Conceptions of wisdom. J. Inf. Sci. 2009, 35, 110-119. [CrossRef]

14. Gugerell, S.H.; Riffert, F. On Defining “Wisdom”: Baltes, Ardelt, Ryan, and Whitehead. Interchange 2011, 42, 225-259. [CrossRef]

15. Rocha, R.G.; Pinheiro, P.G. Organizational spirituality and knowledge management supporting organizational practical wisdom. Spiritual. Stud. 2018, in press.

16. Roos, J. Practical wisdom: Making and teaching the governance case for sustainability. J. Clean. Prod. 2017, 140, 117-124. [CrossRef]

17. Friedland, J.; Jain, T. Reframing the Purpose of Business Education: Crowding-in a Culture of Moral Self-Awareness. J. Manag. Inq. 2020. [CrossRef]

18. Calleja, R.; Melé, D. Valero's “Enterprise Politics": A model of humanistic management and corporate governance. J. Manag. Dev. 2017, 36, 644-659. [CrossRef]

19. Dorst, K. The core of "design thinking" and its application. Des. Stud. 2011, 32, 521-532. [CrossRef]

20. Illes, K.; Zsolnai, L. The role of spirituality in business education. Soc. Bus. Rev. 2015, 10, 67-75. [CrossRef]

21. Mckenna, B.; Biloslavo, R. Human flourishing as a foundation for a new sustainability oriented business school curriculum: Open questions and possible answers. J. Manag. Organ. 2011, 17, 691-710. [CrossRef]

22. Joullié, J.-E. The Philosophical Foundations of Management Thought. Acad. Manag. Learn. Educ. 2016, 15, 157-179. [CrossRef]

23. Haney, A.B.; Pope, J.; Arden, Z. Making It Personal: Developing Sustainability Leaders in Business. Organ. Environ. 2020, 33, 155-174. [CrossRef]

24. Calma, A.; Dickson-Deane, C. The student as customer and quality in higher education. Int. J. Educ. Manag. 2020, 34, 1221-1235. [CrossRef]

25. Tillmanns, T.; Filho, A.S. Reflecting on partnerships of sustainability learning: Enacting a Lewin-Deleuze-Guattari rhizome. Sustainability 2020, 12, 9776. [CrossRef]

26. Woiceshyn, J. A Philosophical Approach to Business Education. Can. J. High. Educ. 1992, 22, 73-91.

27. Nonaka, I.; Takeuchi, H. Humanizing Strategy. Long Range Plann. 2021, 102070. [CrossRef]

28. Marinoff, L. Philosophical Practice; Academic Press: San Diego, CA, USA, 2002; ISBN 9783642253874.

29. Aristotle. The Nicomachean Ethics, 5th ed.; Kegan, P., Trench, T.C., Eds.; Sage Publications: London, UK, 1893.

30. Aquinas, S.T. The Summa Theologica; Translated; 1485. Available online: https://www.documentacatholicaomnia.eu/03d/1225 -1274,_Thomas_Aquinas,_Summa_Theologiae_\%5B1\%5D,_EN.pdf (accessed on 10 January 2021).

31. Pigliucci, M. Wisdom: What Is It? Philos. Mag. 2019, 87, 84-89. [CrossRef]

32. Mitroff, I.I.; Denton, E.A. A Study of Spirituality in the Workplace. Sloan Manag. Rev. 1999, 83-92.

33. Bratianu, C.; Bejinaru, R. Knowledge dynamics: A thermodynamics approach. Kybernetes 2019, 49, 6-21. [CrossRef]

34. Bratianu, C.; Bejinaru, R. The Theory of Knowledge Fields: A Thermodynamics Approach. Systems 2019, 7, 20. [CrossRef]

35. Senge, P.M. The Fifth Discipline: The Art and Practice of the Learning Organization; Doubleday: New York, NY, USA, 1990; ISBN 0385260954.

36. Stead, J.G.; Stead, W.E. Building spiritual capabilities to sustain sustainability-based competitive advantages. J. Manag. Spirit. Relig. 2014, 11, 143-158. [CrossRef]

37. Fernandes Bella, R.; Gonçalves Quelhas, O.; Toledo Ferraz, F.; Soares Bezerra, M. Workplace Spirituality: Sustainable Work Experience from a Human Factors Perspective. Sustainability 2018, 10, 1887. [CrossRef]

38. Schumacher, E.F. Small is Beautiful: Economics as if People Mattered; Blond\&Briggs: London, UK, 1973; ISBN 06-090432-1.

39. Fadiah, N.; Zawawi, M. Organizational sustainability: A redefinition? J. Strateg. Manag. 2019, 12, 397-408. [CrossRef]

40. Muñoz-García, A.; Villena-Martínez, M.D. Sustainable behavior among Spanish university students in terms of dimensions of religion and spirituality. Sustainability 2020, 12, 470. [CrossRef]

41. Hunting, A.; Conroy, D. Spirituality, stewardship and consumption: New ways of living in a material world. Soc. Responsib. J. 2018, 14, 255-273. [CrossRef]

42. Suriyankietkaew, S.; Kantamara, P. Business ethics and spirituality for corporate sustainability: A Buddhism perspective. J. Manag. Spirit. Relig. 2019, 16, 264-289. [CrossRef]

43. Antonakis, J.; Schriesheim, A.C.; Donovan, J.A.; Gopalakrishna-Pillai, K.; Pellegrini, E.K.; Rossomme, J.L. Methods for studying leadership. In The Nature of Leadership; SAGE Publications Inc.: Thousand Oaks, CA, USA, 2004; pp. 48-70.

44. Corbin, J.; Strauss, A. Basics of Qualitative Research: Techniques and Procedures for Developing Grounded Theory, 3rd ed.; SAGE Publications Inc.: Los Angeles, CA, USA, 2008; ISBN 978-1-4129-0644-9.

45. Silverman, D. Interpreting Qualitative Data: Methods for Analysing Talk, Text and Interaction; Sage Publications: London, UK, 2001; ISBN 0761968652. 
46. Flick, U. Métodos Qualitativos na Investigação Científica, 1st ed.; Monitor-Projectos e Edições: Lisbon, Portugal, 2005; ISBN 9729413673.

47. Yin, R.K. Case Study Research: Design and Methods, 4th ed.; Sage Publications Inc.: Los Angeles, CA, USA, 2013 ; ISBN 9781412960991.

48. Fassinger, R.; Morrow, S.L. Toward best practices in quantitative, qualitative, and mixed-method research: A social justice perspective. J. Soc. Action Couns. Psychol. 2013, 5, 69-83. [CrossRef]

49. Godoy, A.S. Pesquisa Qualitativa: Tipos Fundamentais. Rev. Adm. Empres. 1995, 35, 20-29. [CrossRef]

50. Günther, H. Pesquisa qualitativa versus pesquisa quantitativa: Esta é a questão? Psicol. Teor. Pesqui. 2006, 22, 201-209. [CrossRef]

51. Marconi, M.D.A.; Lakatos, E.M. Metodologia Científica, 5th ed.; Atlas: São Paulo, Brazil, 2011; ISBN 978-85-224-4762-6.

52. Macnaghten, P.; Myers, G. Qualitative Research Practice; Seale, C., Gobo, G., Gubrium, J.F., Silverman, D., Eds.; Paperback; SAGE: London, UK, 2007; ISBN 9781412934206.

53. Ezzy, D. Qualitative Analysis: Practice and Innovation; Routledge: London, UK, 2002; ISBN 0-415-28126-1.

54. Couper, M.P.; Hansen, S.E. Computer-Assisted Interviewing. In Handbook of Interview Research: Context E Method; Gubrium, J.F., Holstein, J.A., Eds.; Sage Publications Inc.: Thousand Oaks, CA, USA, 2001; pp. 557-601, ISBN 0-7619-1951-1.

55. Shuy, R.W. In-Person versus Telephone Interviewing. In Handbook of Interview Research: Context E Method; Gubrium, J.F., Holstein, J.A., Eds.; Sage Publications Inc.: Thousand Oaks, CA, USA, 2001; pp. 537-555, ISBN 0-7619-1951-1.

56. Warren, C.A.B. Qualitative Interviewing. In Handbook of Interview Research: Context E Method; Gubrium, J.F., Holstein, J.A., Eds.; Sage Publications Inc.: Thousand Oaks, CA, USA, 2001; pp. 83-101, ISBN 0-7619-1951-1.

57. Johnson, J.M. In-Depth Interviewing. In Handbook of Interview Research: Context E Method; Gubrium, J.F., Holstein, J.A., Eds.; Sage Publications Inc.: Thousand Oaks, CA, USA, 2001; pp. 103-119, ISBN 0-7619-1951-1.

58. Resch, K.; Enzenhofer, E. Collecting Data in Other Languages-Strategies for Cross-Language Research in Multilingual Societies. In The SAGE Handbook of Qualitative Data Collection; Flick, U., Ed.; SAGE Publications Ltd.: London, UK, 2018; pp. 131-147, ISBN 978-1-4739-5213-3.

59. Jenks, C.J. Recording and Transcribing Social Interaction. In The SAGE Handbook of Qualitative Data Collection; Flick, U., Ed.; SAGE Publications Ltd.: London, UK, 2018; pp. 118-130.

60. Bazeley, P.; Jackson, K. Qualitative Data Analysis with NVIVO, 2nd ed.; SAGE Publications Inc.: Thousand Oaks, CA, USA, 2013; ISBN 978-1-4462-5655-8.

61. O'Kane, P.; Smith, A.; Lerman, M.P. Building Transparency and Trustworthiness in Inductive Research Through Computer-Aided Qualitative Data Analysis Software. Organ. Res. Methods 2021, 24, 104-139. [CrossRef]

62. Bratianu, C. Spiritual Knowledge. In Organizational Knowledge Dynamics: Managing Knowledge Creation, Acquisition, Sharing, and Transformation; IGI Global: Hershey, PA, USA, 2015; pp. 72-102, ISBN 9781466683181.

63. Tischler, L. The growing interest in spirituality in business. J. Organ. Change Manag. 1999, 12, 273-280. [CrossRef]

64. Poole, E. Organisational Spirituality-A Literature Review. J. Bus. Ethics 2009, 84, 577-588. [CrossRef]

65. Brown, R.B. Organizational Spirituality: The Sceptic's Version. Organization 2003, 10, 393-400. [CrossRef]

66. Berger, P.; Luckmann, T. The Social Construction of Reality: A Treatise in Sociology of Knowledge; Penguin Books: London, UK, 1991.

67. Lewin, K. Resolving Social Dilemmas—Selected Papers on Group Dynamics; Lewin, G.W., Ed.; Harper \& Brothers: New York, NY, USA, 1997; ISBN 0863775748.

68. Hislop, D.; Bosua, R.; Helms, R. Knowledge Management in Organizations: A Critical Introduction, 3rd ed.; Oxford University Press: Glasgow, UK, 2013.

69. Bui, H.T.M. From the fifth discipline to the new revolution: What we have learnt from Senge's ideas over the last three decades. Learn. Organ. 2020, 27, 489-498. [CrossRef]

70. Bandera, C.; Somers, M.; Passerini, K.; Naatus, M.K.; Pon, K. Disruptions as opportunities for new thinking: Applying the studio model to business education. Knowl. Manag. Res. Pract. 2020, 18, 81-92. [CrossRef]

71. Bratianu, C. Knowledge Dynamics. In Organizational Knowledge Dynamics: Managing Knowledge Creation, Acquisition, Sharing, and Transformation; IGI Global: Hershey, PA, USA, 2015; pp. 103-126, ISBN 9781466683181.

72. Nonaka, I.; Takeuchi, H. The Knowledge-Creating Company: How Japanese Companies Create the Dynamics of Innovation; Oxford University Press, Ed.; Oxford University Press: Oxford, UK, 1995.

73. Bratianu, C. A Critical Analysis of Nonaka's Model of Knowledge Dynamics. In Proceedings of the 2nd European Conference on Intellectual Capital, Lisbon, Portugal, 29-30 March 2010; Volume 8, pp. 115-120.

74. Rocha, R.G.; Pinheiro, P.G. Organizational Spirituality: Concept and Perspectives. J. Bus. Ethics 2020, 1-12. [CrossRef]

75. Pawar, B.S. Leadership Spiritual Behaviors Toward Subordinates: An Empirical Examination of the Effects of a Leader's Individual Spirituality and Organizational Spirituality. J. Bus. Ethics 2014, 122, 439-452. [CrossRef]

76. Fry, L.W.; Cohen, M.P. Spiritual Leadership as a Paradigm for Organizational Transformation and Recovery from Extended Work Hours Cultures. J. Bus. Ethics 2009, 84, 265-278. [CrossRef]

77. Fairhurst, G.T.; Grant, D. The Social Construction of Leadership: A Sailing Guide. Manag. Commun. Q. 2010, 24, 171-210. [CrossRef]

78. Vaughan, F. What is Spiritual Intelligence? J. Humanist. Psychol. 2002, 42, 16-33. [CrossRef]

79. Slager, R.; Pouryousefi, S.; Moon, J.; Schoolman, E.D. Sustainability Centres and Fit: How Centres Work to Integrate Sustainability Within Business Schools. J. Bus. Ethics 2020, 161, 375-391. [CrossRef] 
80. United Nations Take Action for the Sustainable Development Goals. Available online: https://www.globalgoals.org/ (accessed on 10 February 2021).

81. Gärtner, C. Wisdom in the Flesh: Embodied Social Practices of Wisdom in Organisations. Philos. Manag. 2011, 10, 29-42. [CrossRef]

82. Statler, M. Developing wisdom in a business school? Critical reflections on pedagogical practice. Manag. Learn. 2014, 45, 397-417. [CrossRef]

83. Miller, N. How Factories Change Production to Quicky Fight Coronavirus. Available online: https://www.bbc.com/worklife/ article/20200413-how-factories-change-production-to-quickly-fight-coronavirus (accessed on 10 January 2021).

84. Betti, F.; Heinzmann, T. From Perfume to Hand Sanitiser, TVs to Face Masks: How Companies Are Changing Track to Fight COVID-19. Available online: https:/ / www.weforum.org/agenda/2020/03/from-perfume-to-hand-sanitiser-tvs-to-face-maskshow-companies-are-changing-track-to-fight-covid-19/ (accessed on 10 January 2021).

85. Saulius, T.; Valanciene, D.; Bilan, S. Critical thinking in contemporary business education: Philosophical perspectives. Transform. Bus. Econ. 2020, 19, 21-37.

86. Ilie, C.; Fornes, G.; Cardoza, G.; Quintana, J.C.M. Development of business schools in emerging markets: Learning through adoption and adaptation. Sustainability 2020, 12, 8448. [CrossRef]

87. Krishnamurthy, S. The future of business education: A commentary in the shadow of the Covid-19 pandemic. J. Bus. Res. 2020, 117, 1-5. [CrossRef] [PubMed] 